\title{
Effectiveness of participation in public social partnership: new views and judgments
}

\author{
Alena Arbuzova ${ }^{1}$, Natalya Pazdnikova ${ }^{2, *}$ \\ ${ }^{1}$ PNIPU, 29, Komsomolsky ave., Perm, 614990, Russia \\ ${ }^{2}$ PNIPU, 29, Komsomolsky ave., Perm, 614990, Russia
}

\begin{abstract}
The paper is devoted to the problems of public social partnership, the importance of the participation of the government, society and business in it is highlighted. The aim of the paper is to demonstrate the need to study the relations of social partnership and the importance of evaluating the effectiveness of the participation of government, society and business in them. Relations between the partnership actors are developing unpredictably, but the directions of state policy demonstrate the vector that is set in Russian practice. The authors analyze the existing theories in the field of social partnership and highlight the theory of stakeholders. The categories "public social partnership" and "public management of labor resources" are formulated. A system of indicators in the actor context is proposed, which assesses the level of participation of each of the partnership actors in the author's ideology of evaluating the effectiveness of participation. The authors' conclusions support the fact that the effectiveness of actors' participation cannot be assessed without a clear understanding of the social policy mechanisms used, as presented in the Russian regulatory framework.
\end{abstract}

\section{Introduction}

There is much talk these days about involving ordinary citizens more definitively and directly in the policy process. Dialogue, deliberation and citizen engagement are considered as the remarkable features of the current forms of public social partnership as attempts of creating collaborative basis for public involvement processes compete with more traditional top-down approaches. Public deliberation, a defining concept of deliberative democracy theory, is experiencing a renaissance among both scholars and policymakers. Televised town halls are now commonplace during election campaigns. Citizen dialogues have been used to elicit informed opinion and to probe for shared public values in conjunction with major policy reform initiatives.

Communications between different public organizations and citizens take an important place in the process of reducing the degree of information asymmetry and ensuring successful co-production and co-delivery of services. A well-functioning modern society requires that state employees treat sympathetically and respectfully citizens and vice versa. However, effective communication is necessary to maintain a healthy relationship and build mutual trust that facilitates co-production.

Citizen participation has been sourced through participative forms such as online technologies, social media and neighborhood meetings. Gordon \& Mugar
(2020) acknowledge that the use of digital platforms to engage citizens in matters that affect is on the rise.

The interaction of society and government has always been considered as a vector of modern state policy, but such interaction has not always had certain forms.

\section{Materials and methods}

There are a plurality of evaluation approaches and methods determining the effectiveness of participation in public social partnership, but according to Abelson J. (2006) they can be divided into three main groups:

1) user-based which assumes different participants have different goals and that evaluation must take them into account;

2) theory-based which is driven by theories and models of public participation and applies normative evaluation universally to any public participation effort;

3) goal-free evaluation which is not constituted by any stated goals and is conducted in the absence of any theory. Most evaluation studies to date fall under the user-based category. Another distinguishing feature of public participation evaluation is the emphasis on either process or outcome evaluation.

\section{Results and Discussion}

The problem of assessing public social partnership participation is connected, firstly, with the fact that the task of defining the end-point of a participation exercise for purposes of measuring effectiveness is often unclear.

\footnotetext{
Corresponding author: pazdnikovan@mail.ru
} 
Possibility of measuring the social impacts of the process, which takes substantial period of time, is difficult to disentangle from other events that are influential to the policy process, may be limited.

Some specialists offer to measure the effectiveness of participation in public social partnership using approaches based on perceived benefits/costs, which are crucial for uninterrupted involvement in collaborative attempts. In cases when involvement is considered as beneficial, it can be regarded with more participation, attendance, committee membership, and member recruitment (El Ansari and Phillips, 2004). The benefits of such involvement are multiple; due to this they can be distributed among all stakeholders, including users, professionals and organisations, hence personal, community and organisational benefits are important. On the personal level, benefits include recognition, enjoyment, skill enhancement improved control, activity, and satisfaction.

At a level of society participation unites the community initiatives (Naylor et al., 2002), and enlarges the volume of community resources that can support the credibility of attempts.

Benefits are defined as performance and satisfaction. In case if we measure it in non-economic terms, we are able to use such notions as "improved decision-making" and "competitiveness". Participation benefits are not easy to define, measure and assign monetary value to, but they could be used to urge politicians of a necessity to change.

The costs of participation are the negative consequences of participating. Absolute costs are determined as the upfront price of a product or service; while opportunity costs are benefits forgone by tying up resources in directly one particular use and withdrawing them available for alternative uses. A good service with an absolute cost of zero (i.e. free) may still have opportunity costs, e.g. time spent volunteering which could otherwise have been in paid employment.

Measuring the costs/benefits of participation has been met with skepticism and suspicion, or conversely interest and enthusiasm.

As far as there are not any properly tested measurement tools, another area of attention that need to be studied arises.

Most of the outcome-oriented empirical research has focused on assessing the impacts of public participation processes on a range of citizen participant attributes. These studies have reported: increased levels of interest and knowledge of public issues; improved capacity for future public involvement; increased propensity for social bond formation; and improved trust of fellow citizens. There has been less research about the direct impacts of public participation on the policy process and political decision-making. What has been produced offers mixed and ambiguous results (e.g., public deliberation can produce outcomes that influence policy but the conditions under which this occurs are not easily identifiable). However, more recent literature finds a strong association between the widely accepted decision outcomes and processes in which agencies are responsive, participants are motivated, the quality of deliberation is high, and the participants have at least a moderate degree of control over the process' (Beierle and Cayford, 2002).

A conceptual map of public participation evaluation can be depicted as it is shown in figure 1. The scheme presents different groups in the process of interaction as well as the stages of the process itself.

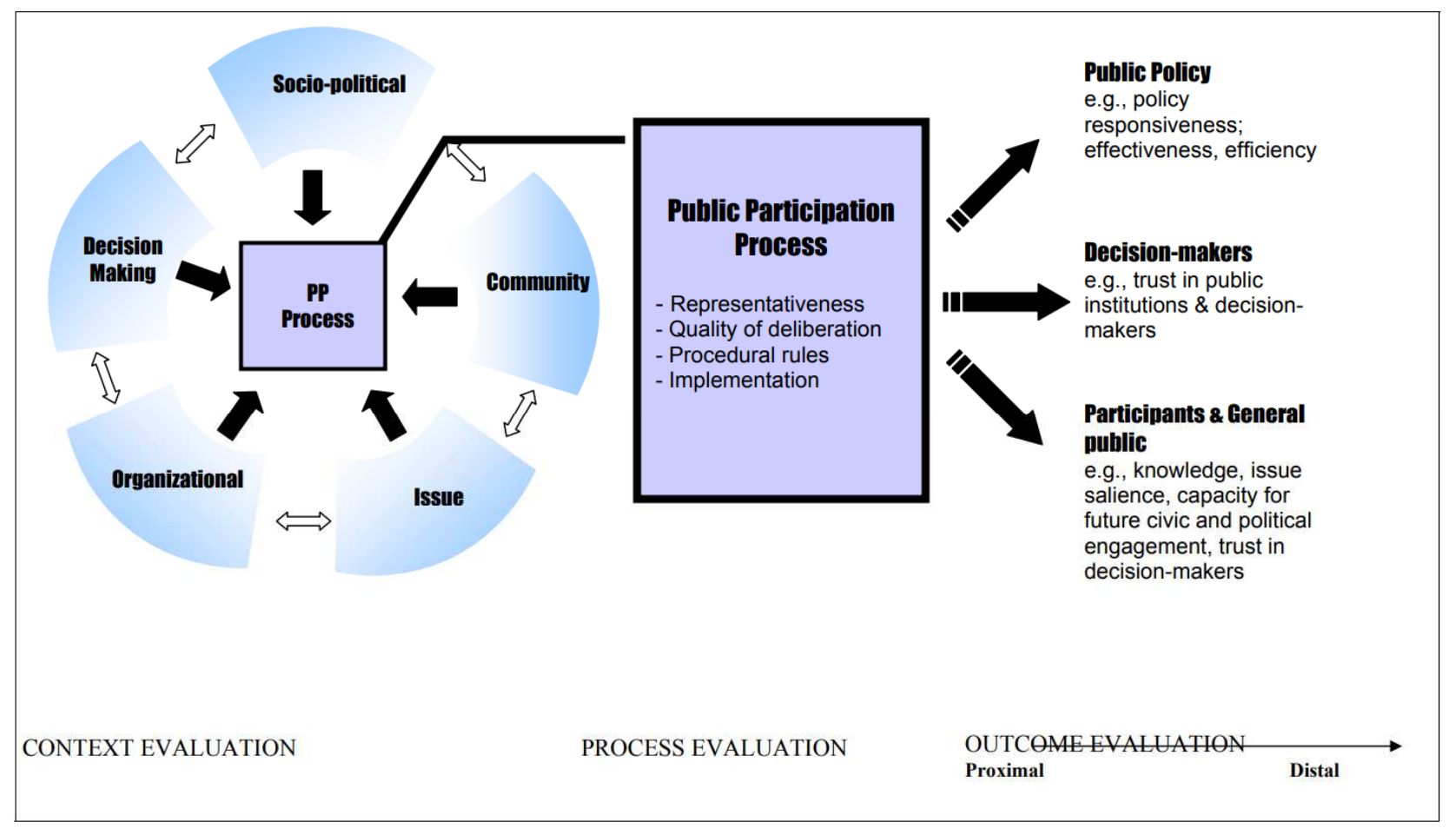

Figure 1: A design of Public Participation Evaluation 
With the introduction of the term "social partnership" in the field of labor relations in the Labor Code of the Russian Federation, the forms of interaction were defined. According to Russian legislation, social partnership is a trilateral relationship between the government, employees (or employees ' representatives) and employers, where trade unions that represent the interests of employees play a special role.

However, when it comes to the public management of the territory's labor resources, the social partnership may acquire a slightly different understanding and form. The fact is that the socio-economic development of regions and their municipalities, as well as the solution of socially significant problems - all this is determined by the resource potential, including labor. In this regard, the labor potential of the territory gives its "fruits" in the case of partnerships between the "power" actor, the "business" actor and the "society" actor, since each of the parties receives its own benefits from such interaction.

Before formulating the concept of "public management of labor resources", it is necessary to identify the category of "public social partnership", which can be understood as a relationship between equal partners aimed at meeting common interests and solving socially significant problems. In general, identification should be carried out within the framework of the "subject-subject" paradigm, and for this purpose, in order to determine the demarcation of the actors of the "power-business-society" partnership, the goals and benefits of each should be established.

Power. The ability of the authorities to assess the state of the labor potential of the territory and to conduct various forms of dialogues with the actors "business" and "society" in order to identify the main problems and suggest ways to solve them. At the same time, the practical interest of the authorities is to increase the level of labor potential through the implementation of project and non - project forms of interaction.

Society. The main advantage for the society from the position of public social partnership means public participation in public administration, and the diverse interests of the population contribute to the choice of directions for the development of the territory as a whole and participation in socially significant events and projects. In this connection, it is possible to distinguish the goals inherent in society in social partnership - the acquisition of social goods of the appropriate quantity and quality; participation in the public control of social processes; awareness of the situation and free movement to places where conditions are more favorable, etc. However, the key goal of the company is to maximize the satisfaction of its own needs and participate in the search and further planning of measures to meet them. At the end of the XX century, Freeman R.E. formulated the "stakeholder theory" or stakeholder concept, based on the understanding that it is necessary to take into account the interests of stakeholders, that is, people and organizations.
Business. The activities of firms, large companies, and individual entrepreneurs are focused on the creation of goods, the provision of services, and the implementation of economic activities, which ultimately forms the country's GDP. That is why business acts as an employer for the population, and its interests are always aimed at obtaining financial benefits (income). Based on this, the goals of business from participation in social partnership are to extract profit and opportunities for its growth from cooperation. Returning to Freeman's theory, we note that stakeholders have a significant influence on business decisions and, in his opinion, private companies should build relationships with all stakeholders.

Thus, in pursuit of their own goals and interests, various actors automatically enter into agency conflicts, the solution of which is possible in the social partnership dialog box, but evaluation problems still exist.

Assessing the effectiveness of actors' participation in social partnership requires not so much the necessary methodology as an adequate system of evaluation indicators.

We see the following system of indicators in the actor context by the example of the Russian Federation (Table 1).

Table 1. Indicators of government, society and business participation in social partnership

\begin{tabular}{|c|c|c|c|}
\hline Indicators & 2019 & 2018 & 2017 \\
\hline \multicolumn{4}{|c|}{ Power (authorities) } \\
\hline $\begin{array}{l}\text { Mortality of the } \\
\text { working-age } \\
\text { population, per } \\
100 \text { thousand } \\
\text { people. }\end{array}$ & 470,0 & 482,2 & 484,5 \\
\hline $\begin{array}{l}\text { The number and } \\
\text { composition of } \\
\text { the labor force, } \\
\text { thousand people. }\end{array}$ & 75398 & 76190 & 76285 \\
\hline $\begin{array}{l}\text { Production of } \\
\text { the gross } \\
\text { domestic } \\
\text { product, billion } \\
\text { rubles. }\end{array}$ & 166056 & 186754 & 195925 \\
\hline $\begin{array}{l}\text { Higher } \\
\text { education } \\
\text { coverage, \% }\end{array}$ & 36,8 & 33,5 & 32,9 \\
\hline $\begin{array}{l}\text { Professional } \\
\text { education } \\
\text { coverage, } \\
\text { thousand people. }\end{array}$ & 3006 & 2931 & 2852 \\
\hline $\begin{array}{l}\text { Average } \\
\text { monthly income } \\
\text { per capita, } \\
\text { thousand rubles. }\end{array}$ & 35249 & 33178 & 31897 \\
\hline $\begin{array}{l}\text { Unemployment } \\
\text { rate }\end{array}$ & $5,4 / 4,6$ & 4,8 & 5,2 \\
\hline
\end{tabular}




\begin{tabular}{|l|c|c|c|}
\hline \multicolumn{3}{|c|}{ Society } \\
\hline $\begin{array}{l}\text { Minimum wage, } \\
\text { (rubles per } \\
\text { month) }\end{array}$ & 11280 & 9489 & 7500 \\
\hline $\begin{array}{l}\text { Number of trade } \\
\text { union members, } \\
\text { million people }\end{array}$ & 19,9 & 20,7 & 25,1 \\
\hline $\begin{array}{l}\text { The value of the } \\
\text { subsistence } \\
\text { minimum per } \\
\text { capita, rubles } \\
\text { per month }\end{array}$ & 11606 & 10328 & 9673 \\
\hline $\begin{array}{l}\text { Number of } \\
\text { initiative } \\
\text { budgeting } \\
\text { projects, pcs. }\end{array}$ & 130 & 102 & 89 \\
\hline $\begin{array}{l}\text { Total number of } \\
\text { territorial public } \\
\text { self-government } \\
\text { (TPSG) projects } \\
\text { received }\end{array}$ & 140 & 116 & 103 \\
\hline \multicolumn{2}{|c|}{ Business } & 73,5 \\
\hline $\begin{array}{l}\text { Net financial } \\
\text { result (profit } \\
\text { minus loss), } \\
\text { RUB million }\end{array}$ & 9036848 & 12400336 & 15758426 \\
\hline $\begin{array}{l}\text { Share of } \\
\text { profitable } \\
\text { organizations, \% }\end{array}$ & 64,1 & 66,9 & 23,96 \\
\hline $\begin{array}{l}\text { Number of PPP } \\
\text { projects, pcs. }\end{array}$ & 179 & 403 & \\
\hline $\begin{array}{l}\text { The volume of } \\
\text { investments in } \\
\text { public-private } \\
\text { partnership } \\
\text { (PPP) projects, } \\
\text { billion rubles. }\end{array}$ & 12,67 & 20,54 & \\
\hline
\end{tabular}

Obviously, the list of indicators depends on the territory under study, its features and factors of the external and internal environment. Clearly, the ideology of evaluating the effectiveness of participation in social partnership of such actors as: "power", "society", "business" can be presented as follows (Figure 2).

The presented matrix of the effectiveness of participation in the social partnership of actors shows the evaluation vectors, in which the initial stage is the analysis and assessment of the problems of civil society. Starting this assessment, we should not forget that at each new stage of development, problems are caused by the situation and the peculiarities of the socio-economy and politics.

In turn, the identified problems determine the setting of goals and objectives for the actors in the social partnership, the achievement of which is evaluated by a system of balanced indicators (performance), which determines the effectiveness of the participation of each actor, in the end.

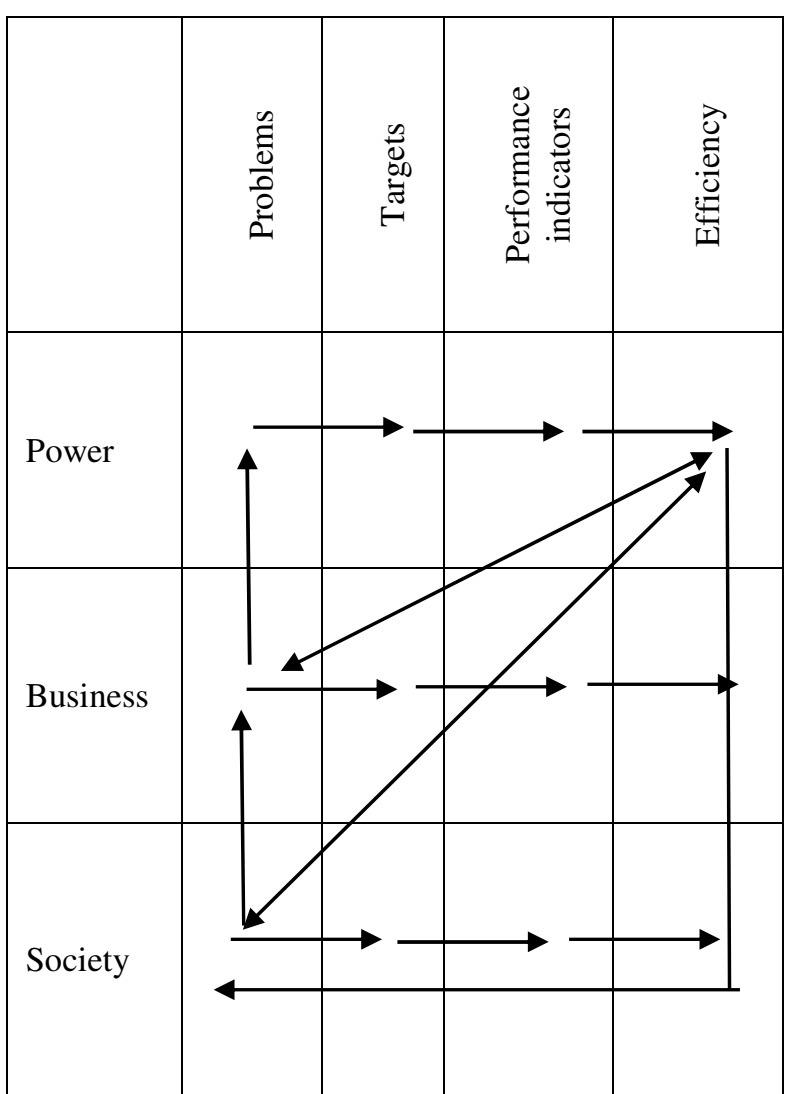

Figure 2 - The ideology of assessing the effectiveness of participation in social partnership

In turn, achieving the maximum effect of participation in social partnership for each actor depends on the vector and directions of social policy and the mechanisms that are defined in it. In our opinion, the mechanisms of social policy can be differentiated in different ways (institutional, socioeconomic, organizational, etc.), but all mechanisms should be determined by the regulatory framework of the Russian Federation.

Thus, the socio-economic mechanisms include:

- budget programs of social design of the population and NGOs;

- provision of grants and subsidies for solving social problems;

-provision of tax benefits to society and business

- projects of territorial public self-

government - projects of initiative budgeting of citizens;

-mechanisms and projects of public-private (municipal-private) partnership;

- funds of local communities;

- volunteerism and volunteering programs;

- mechanisms and programs for strengthening the family, etc.

Institutional and organizational mechanisms include:

- institutions for regulating charitable activities;

- public chambers;

- activities of youth parliaments;

- mechanisms for citizens ' appeals;

- various institutions of business associations (unions of industrialists); 
- public hearings in the budget process;

- public control and public expertise;

- institutions for human rights, for the rights of the child;

- anti-corruption mechanisms, etc.

\section{Conclusion}

Generally, there is a lack of economic assessment of participatory processes and social interventions. This is probably due to the complexity of participatory processes, resistance to the use of economic methods by practitioners or decision-makers, lack of appropriate data, in addition to the cost of undertaking proper economic evaluations.

Of course, the practice of social partnership requires constant regulation by the authorities, but the interest of the participants themselves is obvious, since the solution of socially significant problems for them is possible only together. Thus, the development of public social partnership is possible, firstly, with the implementation of new optimal mechanisms of social policy; secondly, with the presence of social communications between all actors of the partnership; thirdly, the introduction and development of brandoriented business; fourthly, stimulating the interest of participants through various types of benefits provided to them.

\section{References}

1. J. Abelson, Assessing the Impacts of Public Participation: Concepts, Evidence, and Policy Implications (Canadian Policy Research Networks Inc., Ottawa, 2006)

2. El Ansari Walid, Ceri J Phillips, Health Promotion Practice, 5(1) (2004)

3. T. Beierle, J. Cayford, Democracy in practice: Public participation in environmental decisions. (Resources for the Future, Washington DC, 2002)

4. T. Kryshtaleva, The World of economy and management. 17, 3 (2017)

5. V. Galaganov, Organization of the social welfare authorities (Academia, Moscow, 2018)

6. M. Guslova Organization and content of social work with the population (Academia: Moscow, 2018)

7. O. Osipova, Actualization of the social partnership of the university and the enterprise (LAP Lambert Academic Publishing, Moscow, 2018)

8. A. Ollerenshaw, Local Government Studies, 43, (2017) 